\title{
Towards the Curricular Freedom in the Time of Pandemic: A Literature Review
}

\author{
Ahmad Junaidi ${ }^{1,2}$ \\ ${ }^{1)}$ Favulty of Education, Monash University, Australia \\ ${ }^{2)}$ University of Mataram, Indonesia \\ Melbourne, Australia \\ ahmad.junaidi@monash.edu
}

\begin{abstract}
The Ministerial Decree on the Guidelines for Curriculum Implementation in Schools under Special Circumstances (informally referred to as kurikulum darurat) has been devised in response to a nation-wide outcry from teachers, students, and parents as a response to the school closures induced by the Covid-19 pandemic. The government offers three curricular option, i.e., full Curriculum 2013 (K13), ministryadvised K13, and independent curriculum readjustment. However, many questions the readiness and competence of school teachers in responding to the options, especially if opting for the independent curriculum option. This article reviews the literature on the conceptualisation of teacher competence inside and outside the pandemic context, compares the studies on teachers' competence level from two different measures, and links them to the national inequality of access and resources. Both recent and seminal research from inside and outside of Indonesia were reviewed. It aims at providing a broader perspective on the trajectory of the policy. This essay finally advocates that the ministry should openly assert its support for the independent curriculum choice and puts confidence in Indonesian teachers' competence for a fair, contextualised, empathetic education in the time of the pandemic.
\end{abstract}

Keywords- Curricular Freedom, Critical Pedagogical Competence, Kurikulum Darurat

\section{INTRODUCTION}

Covid-19 pandemic continues to transform the established practices in every facet of our economic, social, and cultural life. The term 'new normal', originated from the field of economics, is then appropriated by virtually all the affected fields including education to capture the enacted practices of transformation [1][2]. Schools and universities across the globe have dragged their feet to the new normal practices in the forms of online learning, both asynchronous and synchronous. Indonesia has also responded to the situation by advising all educational institutions to 'study from home' or practicing distant learning through the instruction of its Ministry of Education and Culture (MOEC) and closing its schools [3].

National outcry emerged months after the 'study from home' policy was implemented. There have been copious reports on technological challenges associated with the online learning modality, not only in regions where the infrastructure is lacking and students' access to online learning is limited, but also in the more developed areas [3]-[5]. The psychological and social burden of online learning permeate most of Indonesian households which were metaphorically turned into miniscule underprepared schools with the parents as untrained teachers.
Responding to the challenges, MOEC issued the Ministerial Decree on the Guidelines for Curriculum Implementation in Educational Units under Special Circumstances, informally referred to as kurikulum darurat or emergency curriculum. Each academic unit or school is offered three choices of curricular approach to tackle the issues associated with the challenges of the new normal in their own context [3]. (1) Full K13 option, in which each school can still entirely refer to the National Curriculum of 2013 (K13), (2) Ministry-advised K13 option, in which schools can use the ministry recommended adjustment to the K13 in the form of fixed reductions of curricular goals, and (3) Independent Curriculum option, in which schools can independently readjust their curriculum in the way they see fit.

Option one, the Full K13 option is recommended for the schools with the infrastructure and human resources supportive for its implementation. Considering the majority of schools in the 227 affected regencies and cities [3], only a small number of schools can possibly choose this option. Option two, the ministry-advised K13 option dictates the percentage of reduction in the Basic Competence of each subject. Option three, the independent curriculum option is offered in which the school can adjust the curriculum content and methods of delivery including the reductions rate of each subject to a level they deem best fitting the situation of the school. It is also assured that no national examination will be imposed that will somehow force the schools to match their curricular approach with a high-stake test [3].

This curricular freedom, though emergency induced, is an unprecedented policy in the history of Indonesian national and formal education, at least since the national education has been administered constitutionally and nationally with a top-down approach [6]. Even when school-based curriculum, termed KTSP, was implemented in 2006 until its formal and gradual termination in 2013, the schools were still mandated to comply with a fixed Standards of Competence from which the units of work can be specified independently to meet the local needs of the students [7]. There had been no absolute space for public schools to construct their own curriculum [8].

Unquestionably, schools are expected to do a diagnostic assessment before deciding which option to implement. It is the school board that is responsible in taking the decision after tapping into teachers' insights. Because the first and the second option still operate within the national curriculum, the ministry has provided guide books for teachers, parents, and students [3]. It is the third option of independent curriculum designation that does not receive sufficient attention and encouragement. This literature review is then aimed at answering the crucial 
question of Indonesian teachers' aptness to choose the option of independent curriculum: what competences does a teacher need to device and execute an emergency syllabus in the time of pandemic and do Indonesian teachers have the initial capital to teach within the independent curriculum framework?

\section{METHODS}

This essay reviews the literature on the concepts of teacher competence and research findings on Indonesian teachers' competence. The concept of teacher competence in the time of pandemic is formulated by referring to the concept of competence from the perspective of critical English pedagogy, both from Indonesian and Western perspective. The two conflicting concepts on teachers' competence evaluation (standardised versus contextualised competences) are also discussed by referring to at least 40 research papers on the subject matter. These literatures are then linked to the pandemic situations to suggest considerations for selecting one of the three options.

\section{RESULT AND DISCUSSION}

\section{A. Teacher Competence in The Time of Pandemic}

A fixed conceptualisation of the term teacher competence is vague and difficult to capture [9]. There have been many different conceptions now that it is getting generally accepted that the term is contextual and socially formulated [10]. It is then most sensible for Indonesian context to discuss teacher competence by first consulting to the 2005 Teachers Law. In this conception, there are four intertwining pillars of teacher competences in Indonesia, i.e. pedagogical competence, personality competence, professional competence, and social competences [11].

Concerning the three curricular options, of the four competences, it looks as if the pedagogical competence would be the most fitting group of competence to encapsulate the competences needed to choose the best curricular option. Pedagogical competence deals with the ability to create, execute, and evaluate the instructional design [11]. While it is reasonable to think so, other competences are equally significant. Professional competence is needed to execute the content created as well as working with education technology [12]. Social and personality competence are not less important as teachers have to be even more sensitive, sympathetic, and effectively interact with the students and parents [13]. In the context of the pandemic, the last two competences are intertwined with the first two, creating a unity of competence, resembling a holistic professional competence [14]. In the context of curricular change however, the attention should weigh more on the ability to device a working syllabus for each of the subject within the context of the unforeseeable and challenging times ahead. Authorities in and outside Indonesia have no clear clue on how long the pandemic will force the distant learning to continue to linger [15] [16], demanding the independent curriculum proponents to carefully determine the content size, coverage, and approach to the independent syllabus making by considering the dynamic of the pandemic [16].

Even before the pandemic, the increasing complexity of modern life demands teachers to upgrade their knowledge to engender meaningful learning experience for the students [17]
Paine calls for redefining teachers' ways to see the globalisation beyond just the economic terms, but by treating it as a set of processes in many facets impacting complex human life aspects [18]. However, the phrase 'complexity of modern life' does not consider the pandemic as a variable to be reckoned with. The entire education stakeholders were caught off-guard. Now that the pandemic is here, Peters et al. remind schools and universities to be more affectionate towards to situations faced by the students and should go beyond the totalising rhetoric of standardised science [19]. Synthesising both perspectives, teachers then need to upgrade their pedagogical, professional, social, and personality competence without being held hostage by the obsolete standard of the formal national curriculum and redefine what it means to be cosmopolitan and globalised. Within this concept, infusing the elements of critical pedagogy is, therefore, paramount.

Critical pedagogical competence becomes crucial as the response for the widening education inequality triggered by the pandemic. Dube [20] administered a small study observing the challenges of the rural learners in South Africa, revealing that the online learning as the sole alternative in the time of pandemic severely excludes the disadvantaged learners with limited access in rural areas. Blundell et al. [21] and Andrew et al. [22] reveal that better-off families in England have quantifiable better access not only in the number of learning hours but also the quality of supports, potentially widening the inequality gap. Chachar and Mian [23] reported on the unequal treatment for mental health resulting from the fatigue of online learning and generally, the psychological impact of school's closure in Pakistan. Other recent studies echo many other education inequality related issues, amplifying the call for the teachers to be more empathetic to the needs of the students in the disadvantaged communities and approach the independent curriculum reconstruction with a keen critical pedagogy competence. As Misiaszek [19] even further contends, the diverse inequality experiences from Covid-19 have to be utilised to dissolve non-critical education.

The core of critical pedagogy itself can be traced to the works of Freire [24], Giroux [25], and McLaren [26]. The three scholars painted the biggest strokes, advocating for education as a political act and opposing the banking model of education as manifested in the centralised curriculum. Further, Monchinsky [27] emphasises the co-learning between the teachers and the students by first making the oppressive power of inequality visible in the eyes of the oppressed. This is relevant to the widening disparity aggravated by the pandemic as produced systematically by the inequality of power distribution. Teachers and school leaders within their context should diagnose the oppressive effects of the pandemic and act on it by first co-construct the solutions with the students and parents.

This conception is even crucial in the Indonesian setting. Critical pedagogy has been advocated in various forms, to various extents, in various fields. Tilaar [28][29][6] promotes the term transformative pedagogy advocating for the independence in determining the course of national education by focusing on the Indonesian values without being subjugated by the global capitalistic competition as the standards. Topatimasang, Raharjo, and Fakih [30] call for developing a critical consciousness of how science and education should be organised and liberating the learners to think for themselves. Critical pedagogy has also been discussed in Islamic education 
[31], civic education [32], and English education [33][34]. All calls for a more contextualised, empathetic, and fair education.

In the context of the independent curriculum, critical pedagogy competence is needed to first negotiate the curriculum with the students. Negotiated syllabus has been advocated as a remedy to the coercive standards of statecontrolled curricula [35] [36]. It is a middle ground between giving complete independence of emancipation for the students to take charge of their learning and the dominative oppression of the decision-makers to the students [37]. Negotiating the syllabus means that the rationale of the curriculum is now adjusted to the present challenges, taking sensitivity and empathy towards the severe difficulties faced by parents and students. Diagnostic assessment, as advised by the ministry, can be a space for this endeavour. A practical and health-wise consultation, discussion, and generally negotiated assessment led by the school leaders offer a promising start.

\section{B. Indonesian Teacher Competence: Aptness for Option Three}

Measuring the competence of teachers is a challenging and complicated task [9]. Solely reflecting it in the performance of students is problematic and arduous as the variables for measuring students' success are voluminous. The construct first needs to be made clear, and one framework of measurement in one context is not automatically transferrable to the others [9].

Indonesian teacher competence and within it, teaching performance, has been widely researched, both by the government and private sector evaluators, varying from largely funded projects or even small-scale dissertation research. The National Statistics Agency (BPS) issued national education statistics and claimed that the number of undergraduate certificate holders as the license to teach increased from $89.33 \%$ to $91.76 \%$ [38]. It is acknowledged that this relatively impressive number can not be taken as the reflection of quality, nor to justify the ability to design an independent emergency syllabus, but only as an indication of improvement in quantity. In terms of student-teacher ratio, it is correspondingly emphasised that the ratio is ideally met when referenced to the government standard of a maximum of 20 students per teacher [39].

Larger scale studies, mostly on the teacher certification program, claim that Indonesian teacher competence is generally unsatisfactory in terms of professional and pedagogical knowledge [40][41][42]. World Bank concludes that after more than eight years, in terms of the mastery of specific skills that have an impact on students' learning outcomes, there is virtually no evidence that the certified teachers showed better performance than those who were not [42]. Kusumawardhani [43] used a two-sample instrumental variable method to see the difference between two datasets; the certified and the uncertified teachers. The same findings indicate that there is no significant evidence that certification has a veritable impact on student learning outcomes and teachers' performance. The two studies echo the findings from previous others $[44[[45]$.

More saddening reports are on the results of Teacher Competency Test (UKG), the national test aiming to evaluate teachers' competence of pedagogical and professional competence. In the 2019 test, the average score is $54.8 \%$,
$58.6 \%, 62.3 \%$ and 58.45 for primary schools, junior high school, senior high school, and vocational high school respectively [39]. Taking the reference from the national 2013 Curriculum (K13), the test items are deemed valid and effectively capture teachers' level of competence. The numbers are concurred by Maba and Mantra [46], reporting that primary school teachers' competence in implementing K13 is insufficient. The qualitative analysis reveals that teachers have problems in designing lesson plans as prescribed by the K13.

However, Qoyyimah et al. [47] contend these results by arguing that teachers often act for the best, and their performance is shaped by the contexts after solving the dilemmas between curricular demands and students' situation. This resolving of dilemma indicates that when viewed from the perspective of adherence to the K13 or the teachers' competency tests derived from it, teachers may be labelled incompetent. However, from the teachers' perspective, they were agentic, acting for the benefits of the students in their context. When faced with tensions such as this, professionalism in its own right i.e., acting for the best, can emerge and be driven [48][49]. Teachers indeed have the capacity for contextualisation.

It is then no wonder that there are discrepancies in the research findings on teacher competence. Jailani and Pratiwi categorise Indonesian Mathematics teachers' professional and pedagogical knowledge as sufficient, scoring $82.7 \%$ on average from a small sample from five provinces representing western, central, and eastern Indonesia using a different measure [50]. Suhandani and Julia evaluate certified teachers' pedagogic competence in Sumedang, West Java, a regency with middling Human Development Index of 69.2\% [51][52]. Using Likert scale answered by sixty sample teachers themselves, findings indicate that the teachers evaluated themselves as having sufficient and satisfactory competence. This study yielded the similar finding as Rinantanti et al. [53], reporting on the self-perceived competence of 159 Papuan teachers, a province with one of the lowestHuman Development Index of 59,09 in the time of the study [54]. Ninety-one per cent of participants perceive their overall competency as 'good' and 'very good'. When referenced to the K13 or standardised, these studies show that Indonesian teachers' competency is judged as low. However, teachers often consider themselves competent when considering the context in which their competence is used, i.e., their own classrooms.

\section{Curricular Freedom and Pandemic Challenges}

I have so far presented the literature on the nature of competence in the time of pandemic stemming around the idea that critical pedagogic competence is crucial to subdue the detrimental effect of the standardised curriculum especially when pandemic triggers the widening of inequality. I have also considered Indonesian teachers' competence level, judged incompetent by the national curricular standard, but confident enough when confronted with their performance in their own context. In this section, it is time to consider the three options and engage each option to the pandemic situation.

With schools' health measures, distant learning has become the primary option, relying on internet access, both from smartphones or PC/laptops. The internet penetration rate in 
Indonesia is not categorically reassuring towards this only viable solution. Twelve thousand schools have no internet connections, while forty-eight thousand schools have no proper connection [3]. As for internet access (by any devices), each province differs from another. DKI Jakarta has the highest internet access rate per household, soaring to $93 \%$ [54]. The percentages for West Java, East Java, West Nusa Tenggara, East Nusa Tenggara, and Papua are $77.5 \%, 73.24 \%, 65.25 \%$, $45.83 \%$, and $31.31 \%$ respectively (BPS, 2019). This figure drops when counting the rate of internet access through the device with better learning affordance such as laptop, as compared to smartphones. Only 34\% of Indonesian students have a computer for use at home [14]. Student and teachers' internet access is low, and the rate of this kind of technological poverty varies significantly across the archipelago. With these challenges, the options of Full K13 and Ministry-advised K13 are not empathetic to the situations.

Opting for Full K13 will mean that the curricular goals of K13 have to be met in its entirety and this has been confirmed to cause a severe psychosocial burden for teachers, parents, and the students all across Indonesia [3]. It is; therefore, the second option is offered, and even, strongly advised. The second option advocates reducing the number of curricular goals (called Basic Competence in the 2013 Curriculum). It is expected that by reducing the curricular goals to be achieved, the psychosocial burden can be mitigated [3]. However, in its plan, this option does not distribute the reduction equitably for each subject and each educational level. Consider the insignificant average reduction in Mathematics subject of $27.8 \%$ all across the primary school (SD), junior high schools (SMP) and senior high schools (SMA). However, in a certain grade, and other subjects as in Grade XII SMA, there is no reduction for Mathematics subject, or in Grade VIII SMP, there is no reduction for English Language subject [3]. Other reduction points are showing the same pattern, which is rigid and relatively insignificant. It is insensible to impose the same reduction rate to schools in provinces with different internet and resources availability, making option two equally insensitive. Not to mention that while it is known that the quality of state owned-schools are generally level in Java Island, schools outside Java are struggling in terms of its quality. Of the 100 best achieving schools, only eleven schools are from outside Java [37]. Even worse, the inequality is reflected in the quality of private schools, as their quality depends on the private owners of the schools and are usually less-resourced [56].

\section{CONCLUSION}

It is the most sensible for the Indonesian teachers, led by the school principals, to opt for independent curriculum and be freed to determine their own percentage reprioritising the curricular goals, through a proper diagnosis and confident refocusing of curricular goals. The critical pedagogy competence demands the decision-makers in each school to be more empathetic towards the present situations. The quality of Indonesian teachers, though deemed low, perceive their own capability to take charge of their own educational context as satisfactory. This view has been advocated to be the principle for professional development, which is to see competence as a dynamic rather than static and appropriate the term situated professionalism because competency is only meaningful in context. While the ministry has given the independence for schools to do a diagnostic assessment and then choose the option that best meets the diagnosis, I argue that the emphasis should be placed on option three. When the emphasis is given, swift actions and collaborations can lead to better guidance on syllabus readjustment to suppress the detrimental impact of the top-down curriculum in the time of the pandemic.

\section{ACKNOWLEDGMENT}

I thank the 45 Lombok school teachers voicing their insights on curricular independence.

\section{REFERENCES}

[1] P. Sahu, "Closure of Universities Due to Coronavirus Disease 2019 (COVID-19): Impact on Education and Mental Health of Students and Academic Staff. Cureus, vol. 12, no. 4. 2020. [Online] https://doi.org/10.7759/cureus.7541

[2] L. Darling-Hammond, "Constructing 21st-Century Teacher Education". Journal of Teacher Education, vol. 57 no.3, pp. 300-314, 2016. [Online] https://doi.org/10.1177/0022487105285962

[3] Ministry of Education and Culture (MOEC), "Keputusan Bersama Empat Menteri tentang Panduan Pembelajaran di Masa Pandemi”, 2020. [Online]

https://www.kemdikbud.go.id/main/blog/2020/08/penyesuaian-

keputusan-bersama-empat-menteri-tentang-panduan-pembelajaran-dimasa-pandemi-covid19

[4] P. Wahyono, H. Husamah, and A.S. Budi, "Guru Profesional di Masa Pandemi COVID-19: Review Implementasi, Tantangan, dan Solusi Pembelajaran Daring. Jurnal Pendidikan profesi guru, vol. 1, no. 4. pp. 51-65, 2020.

[5] R.S. Putri, A. Purwanto, R. Pramono, M. Asbari, L.M. Wijayanti, and C.C. Hyun, "Impact of the COVID-19 Pandemic on Online Home Learning: An Explorative Study of Primary Schools in Indonesia. International Journal of Advanced Science and Technology, pp. 4809-4818, 2020

[6] H. A. R, Tilaar, Dimensi-dimensi hak asasi manusia dalam kurikulum persekolahan Indonesia. Yayasan Hak Asasi Manusia, Demokrasi dan Supremasi Hukum. 2001

[7] E.Winarti “The School-Level Curriculum Policy Transfer Process: Learning From A Rural School in Indonesia. International Conference on Education and Language (ICEL) vol. 2, no.4, 2013.

[8] S. Suyanto, "A Reflection on the Implementation of a New Curriculum in Indonesia: A Crucial Problem on School Readiness. AIP Conference Proceedings, 1868(1). 2012. [Online] https://doi.org/10.1063/1.4995218

[9] X. Yang, G. Kaiser, J. König, and S. Blömeke, "Measuring Chinese Teacher professional competence: adapting and validating a German framework in China" Journal of Curriculum Studies, vol. 50 no. 5, pp. $638-653$.
2018.
[Online] https://doi.org/10.1080/00220272.2018.1502810

[10] S. Blömeke, "Modelling Teachers' Professional Competence as a Multidimensional Construct". In S. Guerriero (Ed.), Pedagogical knowledge and the changing nature of the teaching profession. pp. 119-135. 2017. Paris: OECD.

[11] Ministry of Education and Culture (MOEC). Undang-undang Republik Indonesia Nomor 14 Tahun 2005 Guru dan Dosen. 8 Juli 2005. (Lembaran Negara Republik Indonesia Tahun 2005 Nomor 157. 2005. Jakarta

[12] A. Bentri. "Mastery of Primary School Teacher Pedagogy Competency in Curriculum 2013 Implementation in Indonesia. The International Journal of Counseling and Education, vol. 2 no. 2, pp. 78-84. 2017.

[13] F. Mulyani, "Konsep Kompetensi Guru dalam Undang-Undang Nomor 14 Tahun 2005 Tentang Guru dan Dosen (Kajian Ilmu Pendidikan Islam). Jurnal Pendidikan UNIGA, vol. 3 no. 1, pp. 1-8. 2017

[14] X. Zhu."On the Attributes of the Teacher's "Holistic Profession" Quality of Teacher Education and Learning. pp. 53-67. 2017. [Online] https://doi.org/10.1007/978-981-10-3549-4_4

[15] D.M. Morens and A.S. Fauci, "Emerging Pandemic Diseases: How We Got to COVID-19. Cell (Cambridge), vol. 183 no.3, pp. 837-837. 2020. [Online] https://doi.org/10.1016/j.cell.2020.10.022 
[16] F.M. Reimers, and A. Schleicher, "A Framework to Guide an Education Response to the COVID-19 Pandemic of 2020. OECD. Retrieved April, 14, 2020. 2020.

[17] L. Darling-Hammond, and M. Hyler "Preparing educators for the time of COVID ... and Beyond, European Journal of Teacher Education, vol. 43 no. 4, pp. 457-465, 2020. [Online] DOI: 10.1080/02619768.2020.1816961

[18] L. Paine. "Alternative Framing of Teacher Education: a Challenge for Teacher Education in the Age of Globalisation. Quality of Teacher Education and Learning. pp. 85-98, 201. [Online] https://doi.org/10.1007/978-981-10-3549-4_6

[19] M.A. Peters, F. Rizvi, G. McCulloch, P. Gibbs, R. Gorur, M. Hong, Y. Hwang, L. Zipin, M. Brennan, S. Robertson, J. Quay, J.T. Malbon, B Danilo, C. Ronald, P. McLaren, R. Apple, M. Papastephanou, N. Burbules, ... L. Misiaszek, "Reimagining the New Pedagogical Possibilities for Universities Post-Covid-19 An EPAT Collective Project. Educational Philosophy and Theory, pp. 1-44. 2020. [Online] https://doi.org/10.1080/00131857.2020.1777655

[20] B. Dube, "Rural Online Learning in the Context of COVID 19 in South Africa: Evoking an Inclusive Education Approach". Multidisciplinary Journal of Educational Research, vol.10 no.2, pp. 135-157. 2020. [Online] https://doi.org/10.17583/remie.2020.5607

[21] R. Blundell, C. Dias, R. Joyce, and X. Xu "COVID-19 and Inequalities”. Fiscal Studies, vol. 41 no. 2, pp. 291-319. 2020. [Online] https://doi.org/10.1111/1475-5890.12232

[22] A. Andrew et al., "Inequalities in Children's Experiences of Home Learning during the COVID-19 Lockdown in England*", Fiscal Studies, vol. 41, no. 3, pp. 653-683, 2020. [Online] Available: 10.1111/1475-5890.12240.

[23] Mian, A., and Chachar, A. (2020). Debate: COVID-19 and school mental health in Pakistan. Child and Adolescent Mental Health, 25(4), 270-272. [Online] https://doi.org/10.1111/camh.12431

[24] P. Freire, Pedagogy of the oppressed. New York: Continuum, 1970.

[25] H. Giroux, Theory and resistance in education: A pedagogy for the opposition. South Hadley, MA: Bergin and Garvey, 1983.

[26] P. McLaren, Life in schools: An introduction to critical pedagogy in the foundations of education. Routledge, 2015.

[27] T. Monchinski, "Critical Pedagogy in the Everyday Classroom". In Critical Pedagogy and the Everyday Classroom, pp. 115-139. 2008 Springer, Dordrecht.

[28] H. A. R. Tilaar, Pendidikan dalam pembangunan nasiona menyongsong abad XXI, Balai Pustaka, 1990.

[29] H. A. R. Tilaar, Beberapa agenda reformasi Pendidikan nasional dalam perspektif abad 21 (Cet. 1.). 1998. Tera Indonesia.

[30] R. Topitamasang, T. Raharjo, M. Fakih, Mengubahkebijakanpublik. 2007. Insist Press; Yogyakarta

[31] M. Adnan, "Paradigma Pendidikan Kritis dalam Perspektif Pendidikan Islam. Jurnal Studi Keislaman, vol.1, no. 1, pp. 22-34. 2018.

[32] A. Setiarsih, "Diskursus Pendidikan Kritis (critical pedagogy) dalam Kajian Pendidikan Kewarganegaraan." Citizenship Jurnal Pancasila dan Kewarganegaraan, vol. 5, no. 2, pp. 76-85. 2017.

[33] N. Hayati. "Empowering non-native English speaking teachers through critical pedagogy". TEFLIN Journal, vol21, no. 1, 78-89. 2015

[34] A. Junaidi, "Critical English teacher pedagogy: a case of opportunity" in Proceeding of International Graduate Research Symposium 2019. In Chowdury, R. and Van, N. (Eds.), (pp. 55 - 65). Hanoi: VNU Press, 2019

[35] D.F. Clarke, "The Negotiated Syllabus: What is It and How is it Likely to Work?" Applied Linguistics, vol. 12, no. 1, pp. 13-28. 1991

[36] N. Hopkins, "Freedom as Non-Domination, Standards and the Negotiated Curriculum" Journal of Philosophy of Education, vol.49, no. 4, pp. 607-618. 2015. [Online] https://doi.org/10.1080/14681366.2019.1625069

[37] J.L. Kincheloe, Towards a Critical Politics of Teacher Thinking: Mapping the Postmodern. 1993. JF Bergin and Garvey.

[38] Badan Pusat Statistik (BPS), Statistik Indeks Pembangunan Manusia $2019.2019 . \quad$ Jakarta. [Online] https://www.bps.go.id/dynamictable/2020/02/18/1772/indekspembangunan-manusia-menurut-provinsi-metode-baru-20102019.html
[39] Ministry of Education and Culture (MOEC), Neraca Pendidikan Daerah. 2019. [Online] https://npd.kemdikbud.go.id/?appid=ukg.

[40] F. Jalal, M. Samani, M.C. Chang, R. Stevenson, A.B. Ragatz, and S.D. Negara, Teacher Certification in Indonesia: A Strategy for Teacher Quality Improvement (No. 48578, pp. 1-219). The World Bank. 2009. [Online]

http://documents.worldbank.org/curated/en/2009/04/10582109/teacher -certification-indonesia-strategy-teacher-quality-improvement

[41] E. Pisani, "Indonesian kids don't know how stupid they are". Portrait Indonesia. 2013

[42] M.C. Chang, S. Shaeffer, S. Al-Samarrai, A.B. Ragatz, J. de Ree, and R. Stevenson,'Teacher reform in Indonesia: The role of politics and evidence in policy making. Directions in Development-Human Development. Washington, DC: World Bank. 2014. [Online] Retrieved from https://openknowledge.worldbank.org/handle/10986/16355

[43] P. N. Kusumawardhani, "Does Teacher Certification Program Lead to Better Quality Teachers?" Education Economics, vol. 25 no. 6, pp. 590 618. 2017. [Online] https://doi.org/10.1080/09645292.2017.132940

[44] M. Fahmi, A. Maulana, and A.A. Yusuf, "Teacher certification in Indonesia: A Confusion of Means and Ends". Center for Economics and Development Studies (CEDS) Padjadjaran University, vol. 3, no. 1, pp. 1-18. 201.

[45] D. Evans, S. Tate and M. Nicolls "Teacher Education and Professional Development in Indonesia. A Gap Analysis. USAID document. 2009. [Online] http://pdf.usaid.gov/pdf_docs/PNADS282.pdf

[46] W. Maba and I.B.N. Mantra, “An Analysis of Assessment Models Employed by the Indonesian Elementary School Teachers. International Journal of Social Sciences and Humanities, vol. 1, no. 1 , pp. 39-45.

[47] U. Qoyyimah, P. Singh, C. Doherty and B. Exley, "Teachers' Professional Judgement when Recontextualising Indonesia's Official Curriculum to their Contexts. Pedagogy, Culture and Society, vol. 28 no. 2, pp. 1-21. 2019.

[48] G. Kelchtermans, "Dilemmas, Theory, Pedagogy, and Learning in Teachers' Work Lives." Teachers and Teaching, vol. 19, no. 1, pp. 1-3. 2013. [Online] doi:10.1080/13540602.2013.744202

[49] S. Davies, J. Howes, and P. Farrell. "Tensions and Dilemmas as Drivers for Change in an Analysis of Joint Working between Teachers and Educational Psychologists. School Psychology International, vol. 29, no. 4. pp. 400-417. 2008.

[50] R. Pratiwi and Jailani, "The difference of mathematics teachers' content competency in Indonesia. Journal of Physics. Conference Series. 2013. [Online] https://doi.org/10.1088/1742-6596/1097/1/012100.

[51] D. Suhandani and J. Julia, "IdentifikasiKompetensi Guru Sebagai Cerminan Profesionalisme Tenaga Pendidik Di Kabupaten Sumedang (Kajian Pada Kompetensi Pedagogik)". Mimbar Sekolah Dasar, vol. 1, no. 2, pp. 128-141. 2014

[52] Badan Pusat Statistik (BPS), "IPM Kabupaten Sumedang”. 2017. https://sumedangkab.bps.go.id/subject/26/indeks-pembangunanmanusia.html.

[53] Y. Rinantanti, M.A. Rahman, A. Haryanto and B.T. Saidna, "Perception of Senior High School EFL Teachers in Papua, Indonesia Towards Their Own Competence". Journal of Language Teaching and Research, vol. 8, no. 6, pp. 1181-1189. 2017. [Online] https://doi.org/10.17507/jltr.0806.20.

[54] Badan Pusat Statistik, "Statistik Pendidikan 2019". 2020. Jakarta https://www.bps.go.id/publication/2019/11/29/1deb588ef5fdbfba3343 bb51/potret-pendidikan-statistik-pendidikan-indonesia-2019.html.

[55] Badan Pusat Statistik, "Statistik Telekomunikasi 2019". 2019. Jakarta https://www.bps.go.id/publication/2019/12/02/6799f23db22e9bdcf52c 8e03/statistik-telekomunikasi-indonesia-2018.html

[56] J.M. Stern and T.M. Smith, T. M, "Private Secondary Schools in Indonesia: What is Driving the Demand?" International Journal of Educational Development, vol. 46, pp. 1-11. 2016. 